\title{
Tanulmány
}

\author{
Balogh Norbert
}

\section{Zár-rés és nazális hangok időtartamának vizsgálata a nápolyi és torinói regionális köznyelvben}

\begin{abstract}
This study aims to compare the duration of affricate and nasal consonants in the Neapolitan and Turinese regional varieties of spoken Italian. The absolute duration of sounds was measured in a corpus of 100 affricates and nasals - which were then compared by their position in the word such as intervocalic, initial, $\mathrm{CxV}$ and $\mathrm{VxC}$ environments. This paper also considers the analysis of geminated sounds and raddoppiamento sintattico. After the analysis we can see significant differences in the two varieties: in $76 \%$ of the cases the Neapolitan variety represents longer consonant duration compared to the Turinese.

Keywords: affricates, nasals, duration, Neapolitan, Turinese
\end{abstract}

\section{Bevezetés}

A tanulmányom szinkrón olasz dialektális szociofonetikai összehasonlító vizsgálat az olasz élőbeszéd-kutatás területén. A témában Absalom, Stevens \& Hajek (2002), ${ }^{1}$ Celata \& Calamai $(2011)^{2}$ és Stevens $(2011)^{3}$ elméleti kutatásait szeretném akusztikai mérésekkel kiegészíteni, amelyek percepció alapú megállapítások a mássalhangzótartamot illetően.

A kutatásom az olaszul tanulók és az olasz nyelv iránt érdeklődőket célozza meg, felhívva a figyelmüket az olasz regionális köznyelvek egy szeletnyi fonológiai jellegzetességére a hangok kiejtésének időtartama szempontjából.

Kassai (1998: 226) szerint a beszédtempó egy nyelvközösségen belül viszonylag állandó jellemző. Ha viszont az adott nyelvközösségen belüli mindennapi beszélt nyelvet megvizsgáljuk közelebbről, akkor lényeges eltéréseket fogunk tapasztalni. A tanulmányban vizsgált két olasz nyelvváltozat a nápolyi és a torinói regionális köznyelv. A vizsgálat ezek hangjainak kiejtési időtartamával foglalkozik. Ezt két mássalhangzócsoporton belül vizsgálom:

1 A typology of spreading, insertion and delation or what you weren't told about raddoppiamento sintattico in Italian címü cikkükben széleskörben elemzik a raddoppiamento sintattico-t.

2 Chiara Celata és Silvia Calamai a Timing in Italian VNC sequences at different speach rates címü müvükben foglalkoznak részletesen a V-nazális hangok - obstruensek hangkapcsolatával és azok időtartamával.

3 A gemináták vislekedésének elemzéséről írt a Consonant length in Italian: gemination, degemination and preaspiration tanulmányában. 
Balogh Norbert:

Zár-rés és nazális hangok idôtartamának vizsgálata a nápolyi és torinói regionális köznyelvben Argumentum 17 (2021), 83-93

Debreceni Egyetemi Kiadó

DOI: 10.34103/ARGUMENTUM/2021/5

- zár-rés hangok $\left[\mathrm{dz}, \mathrm{d} 3, \mathrm{ts}, \mathrm{t} \int\right]$ és

- nazálisok hangok [m, n, $\mathrm{n}]$.

A tanulmányomban a beszédhangok abszolút időtartalmát vizsgálom, azaz a tényleges kiejtési hosszt, ahogyan azt Laziczius (1979: 107) definiálja. A hangok képzésének kezdetét és végét a Praat (Boersma, P. \& Weenink, D. 1992) hangelemző szoftver segítségével mértem meg. A mért adatok nem mások, mint a korpuszban szereplő 100 hang individuális artikulációs sebessége, amelyeket összehasonlítottam a két regionális köznyelvben.

A fent említett mássalhangzócsoportok elemein kívül azok geminátáit is figyelembe vettem, ahol lehetséges, és a raddoppiamento sintattico-t, azaz az olasz nyelvre jellemző, szókezdő mássalhangzó-kettőzést, amely az előtte álló magánhangzó kötésével jöhet létre.

\section{A vizsgált regionális köznyelvek}

A tanulmányomban az olasz nyelv két regionális köznyelvét elemzem, és szeretném tisztázni az elején, hogy mi is a regionális köznyelv, illetve miért fontos a szerepe különösen Olaszország esetében.

Itáliában a sok száz éves politikai széttagoltság hozzájárult a nyelvi széttagoltsághoz is. A Római Birodalom bukása után az Itáliai-félszigeten több száz évig kisebb-nagyobb területü királyságok, hercegségek, városállamok alakultak ki, amelyek nyelve a latinból fejlödött ki, de eltérö tendenciákat mutattak valamennyi nyelvi szinten. Egységes (Olasz)ország és olasz nyelv hiányában helyi köznyelvek (volgare) bontakoztak ki (pl. lombardiai, toszkán, nápolyi stb). Egységes, nemzeti nyelvröl (italiano standard) 1861-ig, Olaszország egyesítéséig nem is beszélhetünk.

Az új olasz nyelv a toszkán nyelvjárás firenzei változatából ered, amit Bembo jelölt ki sztenderdnek még a XVI. században. Ez hamar problémát okozott, mert a sztenderdnek csak írott változata volt, beszélt nem. Olaszország lakói kétnyelvüvé váltak, megőrizve a dialektusukat és megtanulva a nemzeti nyelvet. Ez a folyamat a mai napig is részben fennáll, de sokan ma már csak egynyelvüek. A lakosság tehát két nyelvet használja, és e kettő mellett kialakultak a regionális köznyelvek (italiano regionale), amelyek az olasz nyelv egy lokális jegyekkel gazdagított változata (Marcato 2002: 91). A regionális köznyelv nem más, mint a szubsztenderd, vagyis az írott sztenderd beszélt változata. E regionális köznyelvek csoportjaira jellemzőek az egyedi hangalaki, szószerkezeti stb. sajátosságok, amelyek egy része a dialektusokból ered. Ezen sajátosságok közül én csupán a hangtani eltérésekkel foglalkozom, a regionális köznyelvek fonetikai különbségeit fogom megvizsgálni. A tanulmányomban vizsgált nyelv a nápolyi és a torinói regionális köznyelv. ${ }^{4}$ A korpuszban nápolyi és torinói születésủ interjúalanyok olaszul beszélnek, azaz a szubsztenderd nyelvben nyilvánulnak meg.

A következőkben, az egyszerübb olvasat kedvéért, a nápolyi és torinói regionális köznyelvet csak nápolyi és torinói köznyelvként fogom említeni.

A nápolyi dialektus Nápoly és környékén, illetve Nápolytól délre terjedt el a félszigeten és 1442-töl a Nápolyi Királyság egyik hivatalos nyelve is volt. A mai nápolyi regionális köznyelvet Campania tartományban beszélik. A torinói regionális köznyelvet Torinó és környékén beszélik Piemont tartományban. Írásban a torinói dialektust már a XII. században is használták, de hivatalos nyelvi státuszt soha nem kapott. Mindkét nagyváros a régió székhelye is, ezért jelentős befolyásuk van a környékükre. 
Balogh Norbert:

Zár-rés és nazális hangok idötartamának vizsgálata a nápolyi és torinói regionális köznyelvben Argumentum 17 (2021), 83-93

Debreceni Egyetemi Kiadó

DOI: 10.34103/ARGUMENTUM/2021/5

\section{A tanulmány célja, feltételezése és módszertana}

Jelen tanulmány korpuszát az Interactive Atlas of Romance Intonation (Prieto, P., BorràsComes, J. \& Roseano, P. 2010-2014) hangfelvételeiböl gyüjtöttöm össze. Az internetes oldal számos újlatin nyelv hang- és videofelvételét tartalmazza, amelyek témája irányított, azzal a céllal, hogy tanulmányokat, összehasonlító elemzéseket lehessen készíteni. A torinói és nápolyi hangfelvételekből választottam ki olyan 100 szót, amelyekben szerepelnek az általam vizsgálandó mássalhangzók. Ezeket a szavakat a Praat program segítségével elemeztem úgy, hogy a kiejtés időtartamát mértem meg. Az alábbi ábra példaként illusztrálja a mezzo szó (magyarul: fél) mérését.

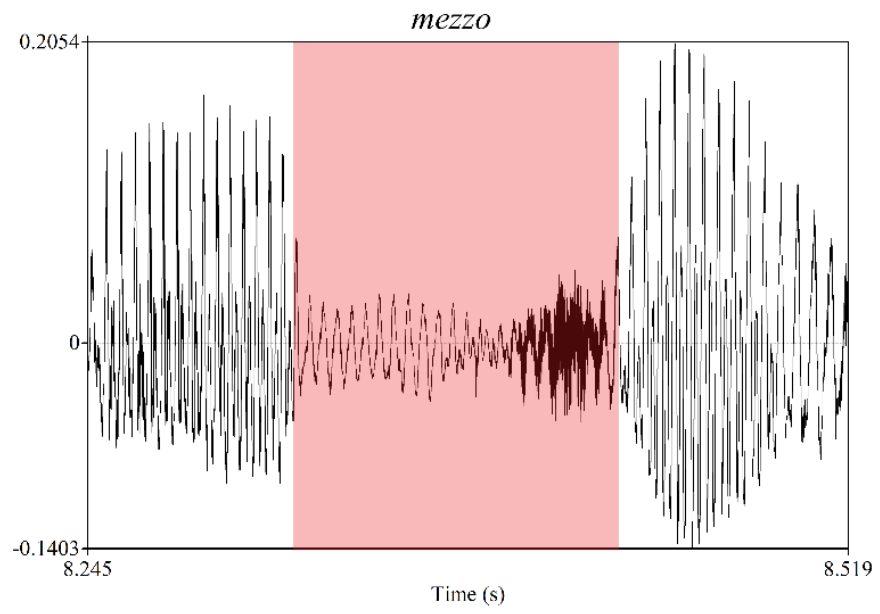

1. ábra. A mezzo szó mérése a Praat szoftverrel. Kisötétitve a [dz] gemináta terjedése.

A korpusz 49 nápolyi és 51 torinói akcentussal kiejtett szó beszédhangjaiból áll. A Praat program a beszéd hanghullámait képen rögzíti és lehetővé teszi azok mérését. Az elemzés 55 zár-rés és 45 nazális hang kijelöléséből és azok méréséből állt. Majd egy összehasonlító elemzés során tendenciákat állapítottam meg a beszélök által realizált hangok időtartamáról. Az elemzett szöveg nem szolgáltatott minden esetben mintát, így ezek nulla értékkel jelennek meg a táblázatokban. Ezáltal a nem összehasonlítható eredményeket mellőztem a vizsgálatból. Az alábbi táblázatban találhatók részletesen a mintavételben szereplő beszédhangok. Az első oszlopban jelölöm a vizsgált hangokat, majd egy-egy példát azokra a szavakra, amelyekben ezek megtalálhatók és elemzésre kerültek. Vastag jelöléssel utalok a hangkörnyezetre. A harmadik és negyedik oszlopban a nápolyi és torinói mintavétel számai szerepelnek darabban, majd ezek teljes összege. 
Balogh Norbert:

Zár-rés és nazális hangok idôtartamának vizsgálata a nápolyi és torinói regionális köznyelvben Argumentum 17 (2021), 83-93

Debreceni Egyetemi Kiadó

DOI: 10.34103/ARGUMENTUM/2021/5

\begin{tabular}{|c|c|c|c|c|}
\hline Regionális köznyelv & $\begin{array}{c}\text { Néhány példa a } \\
\text { megvizsgált } \\
\text { szavakra } \\
\end{array}$ & Nápolyi & Torinói & Összesen \\
\hline Zár-rés hangok & & & & \\
\hline$[\mathrm{t}]]$ & cerchio, vicino & 11 & 10 & 21 \\
\hline$[\mathrm{t} f:]$ & faccio, tracciato & 2 & 2 & 4 \\
\hline [d3] & gioco, logico & 2 & 4 & 6 \\
\hline [dz:] & maggiolone & 1 & 3 & 4 \\
\hline [ts] & inizia, direzione & 4 & 5 & 9 \\
\hline [ts:] & pezzo, altezza & 0 & 2 & 2 \\
\hline [dz] & Zazà & 2 & 0 & 2 \\
\hline [dz:] & mezzo, magazzino & 5 & 2 & 7 \\
\hline Zár-rés hangok összesen & & 27 & 28 & 55 \\
\hline Nazális hangok & & & & \\
\hline [m] & fiume. prima & 7 & 6 & 13 \\
\hline [m:] & stammi, dimmi & 1 & 2 & 3 \\
\hline [n] & viene, sinistra & 9 & 14 & 23 \\
\hline [n:] & stanno & 2 & 0 & 2 \\
\hline [n] & disegni, ignoralo & 3 & 1 & 4 \\
\hline Nazális hangok összesen & & 22 & 23 & 45 \\
\hline Összesen & & 49 & 51 & 100 \\
\hline
\end{tabular}

1. táblázat. A korpuszban szereplö mintavétel eloszlása hangonként

Az analízisben szerepelnek tehát rövid mássalhangzók, hosszú vagy kettőzött mássalhangzók (vagyis gemináták) és az olasz nyelvre jellemző raddoppiamento sintattico jelensége, azaz szóeleji mássalhangzónyújtás.

Mindkét köznyelv elemzett szövege interjú típusú, ahol egy férfi és egy nő útbaigazításszerü feladatot (map task) kapott, megadott paraméterek alapján. Az egyiknél lévő térkép egy útvonallal van ellátva - ő lesz az instrukcióadó, míg a másiknál nem lesz megjelölve az útvonal, ezért kérdéseket kell feltennie, hogy elérjen a célhoz. A torinói hangfelvétel 15 p 17 s és 2445 szót tartalmaz, míg a nápolyi 8 p 39 s és 1165 szó.

A hangfelvételen szereplő személyek mind egyetemi hallgatók, egy 22 éves nápolyi nő, egy 26 éves nápolyi férfi, valamint egy 18 éves torinói nő és egy 23 éves torinói férfi, vagyis elmondható, hogy jól iskolázottak és fiatalok (18-26 év közöttiek). Mindnyájan az adott nagyvárosban születtek, illetve élnek, ezzel meggyőződhetünk arról, hogy a regionális köznyelv, amit használnak, eredeti és a vizsgálatuknak megfelel.

A férfiak által kiejtett beszédhangok száma 68, a nők által pedig 32. Hasonló mintavétel a nemek között azért nem volt lehetséges, mert a férfiak voltak mindkét esetben az instrukcióadók, ezért ők sokkal többször szólaltak meg és hosszabb terjedelemben beszéltek.

A beszédhangok pozícióját tekintve 52 intervokális (V_V), 27 szókezdő, 6 mássalhangzó előtti (_C), 2 mássalhangzó és magánhangzó közötti (C_V), 10 magánhangzó és mássalhangzó közötti (V_C) és 3 szóvégi, amelyet magánhangzó elöz meg (V_\#). Ezekben a hangkörnyezetekben végeztem el a méréseket, amelynek a célja az volt, hogy bemutassa a kiejtett hangok 
Balogh Norbert:

Zár-rés és nazális hangok idötartamának vizsgálata a nápolyi és torinói regionális köznyelvben Argumentum 17 (2021), 83-93

Debreceni Egyetemi Kiadó

DOI: 10.34103/ARGUMENTUM/2021/5

időtartamának különbségét a két olasz köznyelv között. A beszédhangok pozíciója tekintetében minél több lehetőséget szerettem volna elemezni, hiszen, ahogyan azt a továbbiakban látni fogjuk, ugyanannak a hangnak a kiejtési hossza még egyazon nyelvben is eltérő lehet, attól függően, hogy milyen pozícióban helyezkednek el a szóban. Például a gioco és a logico [d3] hangjának időtartama eltérő, mert az első szókezdő helyzetben van, míg a második vokálisok között.

Az északolasz regionális köznyelvek hangidőtartamai köztudottan rövidebbek, mint a délieké, illetve a raddoppiamento sintattico az északi dialektusokban nagyon korlátozott. Ezt mutatják az északolasz dialektusokra jellemző degeminációs jelenségek, ahogyan Grassi (2004: 77) és Ledgeway (2016: 188) is írják. Az intervokális dentális és alveoláris affrikáták a sztenderdtől való eltérése kapcsán viszont Canapari (1980: 23, 72) megjegyzi, hogy a délolasz intervokális [dz] ejtése hosszú, azonban az északolasz [n], amely kiejtése mindig hosszú kellene, hogy legyen, lerövidül vagy [nj]-be hajlik át (Canapari 1980: 99). Továbbá Devoto (2002: 113) és Loporcaro (2009:128) szerint a szóeleji mássalhangzó-kettőzés gyakori alkalmazása a déli regionális köznyelvekre jellemző.

A fent említett különbségek nem szorulnak bizonyításra, az én célom ezeknek a jelenségeknek a konkrét mérési adatokkal való alátámasztása. Feltételezem, hogy a szavak időtartamának megmérése és azok összehasonlításának eredménye bizonyítani fogja a nápolyi és a torinói regionális nyelv különbségeit.

\section{$4 \quad$ A vizsgálat bemutatása}

\subsection{Zár-réshangok}

A zár-rés hangok, azaz az affrikáták képzése összetett. Egyfelöl zár képződik a szájüregben, a felpattanást követően a zár réssé nyílik és onnan távozik a képzési levegő ezzel létrehozva a hangjelenséget. Az alveoláris [t $\mathrm{t}]$ és a [d3] képzésénél a nyelvhát megemelkedik és a kemény szájpadláshoz tapad, ekkor keletkezik a zár (Herczeg 1992: 37). A dentális [dz] és a [ts] esetében a zár a fogmedrek felett jön létre. A zár-rés hangok esetében a réshangképzést vettem alapul, ahol a hangképzés történik, vagyis a felpattanástól végeztem el a mérést. 
Balogh Norbert:

Zár-rés és nazális hangok idötartamának vizsgálata a nápolyi és torinói regionális köznyelvben Argumentum 17 (2021), 83-93

Debreceni Egyetemi Kiadó

DOI: 10.34103/ARGUMENTUM/2021/5

\subsubsection{Az alveoláris affrikáták}

\begin{tabular}{|c|c|c|c|c|c|c|c|}
\hline \begin{tabular}{|l} 
Előfordulása \\
\end{tabular} & $\mathbf{V}_{2} \mathbf{V}$ & Átlag (ms) & \multicolumn{2}{|c|}{ C_ Átlag (ms) } & \multicolumn{2}{|c|}{ Szókezdő Átlag (ms) } & \multirow[t]{2}{*}{ Összesen } \\
\hline Nápolyi & & & & & & & \\
\hline$[\mathrm{t} f]$ & 3 & 38 & 1 & 47 & 7 & 48 & 11 \\
\hline$[\mathrm{t} f:]$ & 2 & 45,5 & 0 & - & 0 & - & 2 \\
\hline [d3] & 0 & - & 0 & - & 2 & 47,5 & 2 \\
\hline [dz:] & 1 & 38 & 0 & - & 0 & - & 1 \\
\hline Nápolyi összesen & 6 & & 1 & & 9 & & 16 \\
\hline Torinói & & & & & & & \\
\hline$\left[\mathrm{t} \int\right]$ & 4 & 33 & 1 & 40 & 5 & 39 & 10 \\
\hline$[\mathrm{t} f:]$ & 2 & 37,5 & 0 & - & 0 & - & 2 \\
\hline [d3] & 1 & 35 & 0 & - & 3 & 30 & 4 \\
\hline [dz:] & 3 & 29 & 0 & - & 0 & - & 3 \\
\hline Torinó összesen & 10 & & 1 & & 8 & & 19 \\
\hline Összesen & 16 & & 2 & & 17 & & 35 \\
\hline
\end{tabular}

2. táblázat. A vizsgált alveoláris affrikáták eloszlása és átlagos idötartama. A táblázat átlagértékei milliszekundumban vannak megadva.

A 2. táblázatban látható, hogy szókezdő helyzetben a zöngétlen [t $\left.\int\right]$-nek a nápolyi köznyelvben az átlagos hangidőtartama $48 \mathrm{~ms}$, míg a torinóiban $39 \mathrm{~ms}$-ot figyeltem meg. A [t $\mathrm{f}]$ intervokális környezetben hasonló értékeket mutat a két köznyelvben: a torinói $33 \mathrm{~ms}$ és a nápolyi $38 \mathrm{~ms}$. Ezek különbségértéke viszont kevesebb, mint az előző mérésben szereplőké, jóllehet ez az érték ismét növekedést mutat a [tf:] gemináta esetén intervokális pozícióban, ahol az átlagosan: 45,5 ms a nápolyiban, míg a torinóiban $37,5 \mathrm{~ms}$. A [t $\int$ ] mássalhangzó utáni helyzetben a nápolyiban átlagosan $47 \mathrm{~ms}$, míg a torinóiban $40 \mathrm{~ms}-\mathrm{ot}$ mutat. A [t]] esetében azt látunk, hogy a déli dialektusban az értékek minden megvizsgált pozícióban nagyobbak, ami bizonyítja a feltételezésemet.

A zöngés [d3] szókezdő pozícióból vett értékei a torinói köznyelvben átlagosan 30 ms, míg a nápolyiban 47,5 ms. Érdemes megvizsgálni ebben az esetben közelebbről a kapott eredményeket, mert ez utóbbi mérési értéke több, mint 50\%-os. A nápolyi köznyelvnél egyértelmüen hallható a szó eleji mássalhangzó megnyújtás. A hangkötést a torinói köznyelvben a beszélő nem használja ki, pedig a környezete adott, viszont ismert is, hogy az északolasz dialektusok nem használják a raddoppiamento sintattico-t. Így ebben az esetben is érvényesül vizsgálatom bizonyítása, miszerint a délolasz köznyelvekben elterjedtebb a raddoppiamento sintattico.

A nápolyi és torinói [dz:] gemináta átlagértékei 38 ms és 29 ms. A kapott értékek közötti eltérés nagysága 30\%-os, amely szintén számottevő.

Érdemes közelebbröl is megnézni a [t $\mathrm{t}:]$ és a [dz:] gemináták részleteit. Azt látjuk, hogyha egy adott nyelv rövid mássalhangzóit és azok geminátáit összehasonlítom, akkor ez utóbbi mért értéke nem lesznek duplája az előbbinek, pedig kettőzve ejtem. Ez azzal magyarázható, hogy a zár-rés hangoknál nem a ténylegesen kiejtett hang hossza fog lényegesen megnőni, hanem a 
Balogh Norbert:

Zár-rés és nazális hangok idötartamának vizsgálata a nápolyi és torinói regionális köznyelvben Argumentum 17 (2021), 83-93

Debreceni Egyetemi Kiadó

DOI: 10.34103/ARGUMENTUM/2021/5

zárszakaszban felgyülemlett szünet és ez eredményezi a hang megkettőzött ejtését. Ez a különbség a vizsgálatban azért nem látványos, mert én, ahogyan korábban jeleztem, csak a felpattanási zörejt mértem.

Összegezve, az látható a megmért adatok alapján, hogy minden megvizsgált hangkörnyezetben a nápolyi köznyelvben hosszabb időtartamban ejtik ki az alveoláris affrikátákat, mint a torinói köznyelvben.

\subsubsection{A dentális affrikáták}

Az olasz nyelvben az ortográfiai 'z' két hangnak is megfelel: a zöngétlen [ts] és a zöngés [dz]. Vizsgálatuk ezért külön történik. A [ts] kilencszer, a [ts:] kétszer fordul elő mintavételünkben, míg a [dz] kétszer, a geminátája [dz:] pedig hétszer. Kiejtésük átlagos időtartama milliszekundumban van megadva az alábbi táblázatban.

\begin{tabular}{|l|cc|cc|cc|c|}
\hline Elöfordulása & V_V & Átlag (ms) & C_ & Átlag (ms) & Szókezdó Átlag (ms) & Összesen \\
\hline Nápolyi & & & & & & & \\
[dz] & 1 & 35 & 0 & - & 1 & 39 & 2 \\
[dz:] & 5 & 36 & 0 & - & 0 & - & 5 \\
[ts] & 3 & 83 & 1 & 41 & 0 & - & 4 \\
[ts:] & 0 & - & 0 & - & 0 & - & 0 \\
Nápolyi összesen & 9 & & 1 & & 1 & & 11 \\
\hline Torinói & & & & & & & \\
[dz] & 0 & - & 0 & - & 0 & - & 0 \\
[dz:] & 2 & 41 & 0 & - & 0 & - & 2 \\
[ts] & 2 & 63 & 3 & 65 & 0 & - & 5 \\
[ts:] & 2 & 85 & 0 & - & 0 & - & 2 \\
Torinó összesen & 6 & & 3 & & & & 9 \\
\hline Összesen & 15 & & 4 & & 1 & & 20 \\
\hline
\end{tabular}

3. táblázat. A dentális affrikáták eloszlása és átlagos időtartama a mintavételben

A [ts] átlagértéke C[ts]V pozícióban a nápolyi köznyelvben $41 \mathrm{~ms}$, míg a torinóiban $65 \mathrm{~ms}$. A torinói érték lesz nagyobb az elvárttal szemben, ráadásul 50\%-kal, ami nem csekély. A [ts] intervokális környezetben a nápolyiban $83 \mathrm{~ms}$ értékkel bír, a torinói átlagérték ezzel szemben csak $63 \mathrm{~ms}$, amely viszont hozza az elvárt értéket. A [ts:] gemináta torinói átlagértéke $85 \mathrm{~ms}$, a nápolyi köznyelvben nem szerepelt ilyen hangkombináció egyszer sem a mintavétel alapját képező interjúban, ezért nem tudjuk érdemben összehasonlítani. (Valószínüleg nagyobb értékkel bír, mint a rövid mássalhangzója, hasonló arányok várhatók, mint ahogyan a torinói értékek is mutatják.)

A [dz] szókezdő helyzetben a nápolyiban 39 ms, amely érték intervokális helyzetben 35 msra csökken. A torinói minta hiányos ebben az esetben, mert nem volt ilyen példa az interjú során. A nápolyi és a torinói [dz:] gemináta értékei 36 ms és 41 ms, amelyek jóllehet nagyságrendre kevés különbséggel bírnak, mégis a torinói értéke a nagyobb, ami a feltételezésemmel ellentétes. 
Balogh Norbert:

Zár-rés és nazális hangok idötartamának vizsgálata a nápolyi és torinói regionális köznyelvben Argumentum 17 (2021), 83-93

Debreceni Egyetemi Kiadó

DOI: 10.34103/ARGUMENTUM/2021/5

A [dz] és a geminátája értékei is nagyon hasonlóak egymáshoz, ez azért van, mert csak hosszú hangként fordulhatnak elő mindkét esetben (Herczeg 1992: 37). A mérési adatok ezt megerősítik.

Összefoglalva, a dentális affrikáták között a zöngétlen [ts] és a zöngés [dz] hangoknál is tapasztatunk olyan eseteket, amikor a torinói köznyelvben hosszabb időtartamú eredményeket kaptunk, mint a nápolyiban. Ezek az esetek az intervokális [dz:] és a mássalhangzót követő [ts] voltak, viszont azt is látjuk, hogy ezek nem konzekvensek, mert az elsőnél nem tapasztaltuk ugyanazt a jelenséget rövid mássalhangzónál, illetve a másiknál pedig annak geminátája esetén. Az alveoláris affrikátákkal összevetve, a mintavétel is kisebb volt, megfelelő minta híján, ezért a kapott eredményeket óvatosan kell kezelni.

\subsection{Nazálisok}

A másik nagy csoport, amely a tanulmány vizsgálatát képezi az orrhangok csoportja, azaz a nazális hangok. Képzésük során a szájüregben létrejött zár felpattanásakor a levegő az orron át távozik, létrehozva így a hangot. A zár az ajkakkal az [m]-nél, a felső fogmedreknél az [n]-nél és a kemény szájpadlás középső részénél az [n]-nél jön létre.

A 4. táblázatban látható, hogy a zöngés [m] hanggal nápolyi intervokális környezetben 90 ms, míg a torinói $50 \mathrm{~ms}$, ami majdnem 50\%-kal kevesebb értékkel bír. Ezek az értékek viszont teljesen átrendeződnek szókezdő pozícióban: a nápolyi csak $25 \mathrm{~ms}$, míg a torinói $60 \mathrm{~ms}$. További hangkörnyezetekben, mint $\mathrm{V}[\mathrm{m}] \mathrm{C}$ és $\mathrm{C}[\mathrm{m}] \mathrm{V}$, pedig már megnövekedett átlagértékeket látunk (40 ms, $50 \mathrm{~ms})$ a nápolyiban. A raddoppiamento sintattico-t nem használja ki egyik köznyelv sem, viszont gemináták esetén az értékek a következőképpen alakultak: nápolyi 140 ms, torinói $90 \mathrm{~ms}$, ezzel visszaállt a feltételezett rend. Tehát összefoglalva az [m] intervokális helyzetben és gemináták esetén a nápolyi köznyelvben hosszabb időtartamokat hoznak, mint a torinóiban.

\begin{tabular}{|c|c|c|c|c|c|c|c|c|c|c|c|}
\hline Előfordulása & V_V & $\begin{array}{c}\text { Átlag } \\
(\mathbf{m s})\end{array}$ & V_\# & $\begin{array}{c}\text { Átlag } \\
(\mathbf{m s})\end{array}$ & V_C & $\begin{array}{c}\text { Átlag } \\
\text { (ms) }\end{array}$ & C_V & $\begin{array}{c}\text { Átlag } \\
(\mathrm{ms})\end{array}$ & Szókezdő & $\begin{array}{c}\text { Átlag } \\
(\mathrm{ms})\end{array}$ & Összesen \\
\hline Nápolyi & & & & & & & & & & & \\
\hline $\begin{array}{l}{[\mathrm{m}]} \\
{[\mathrm{m}:]}\end{array}$ & $\begin{array}{l}3 \\
1\end{array}$ & $\begin{array}{c}90 \\
140\end{array}$ & $\begin{array}{l}0 \\
0\end{array}$ & $\begin{array}{l}- \\
-\end{array}$ & $\begin{array}{l}1 \\
0\end{array}$ & $\begin{array}{l}40 \\
-\end{array}$ & $\begin{array}{l}1 \\
0\end{array}$ & $\begin{array}{l}50 \\
-\end{array}$ & $\begin{array}{l}2 \\
0\end{array}$ & $\begin{array}{l}25 \\
-\end{array}$ & $\begin{array}{l}7 \\
1\end{array}$ \\
\hline [n] & 4 & 75 & 1 & 60 & 2 & 125 & 1 & 70 & 1 & 50 & 9 \\
\hline [n:] & 2 & 105 & 0 & - & 0 & - & 0 & - & 0 & - & 2 \\
\hline [n] & 3 & 100 & 0 & - & 0 & - & 0 & - & 0 & - & 3 \\
\hline Náp. össz. & 13 & & 1 & & 3 & & 2 & & 3 & & 22 \\
\hline Torinói & & & & & & & & & & & \\
\hline$[\mathrm{m}]$ & 2 & 50 & 0 & - & 0 & - & 0 & - & 4 & 60 & 6 \\
\hline [m:] & 2 & 90 & 0 & - & 0 & - & 0 & - & 0 & - & 2 \\
\hline [n] & 3 & 45 & 2 & 40 & 7 & 70 & 0 & - & 2 & 55 & 14 \\
\hline [n:] & 0 & - & 0 & - & 0 & - & 0 & - & 0 & - & 0 \\
\hline [n] & 1 & 70 & 0 & - & 0 & - & 0 & - & 0 & - & 1 \\
\hline Torinói össz. & 8 & & 2 & & 7 & & 0 & - & 6 & & 23 \\
\hline Összesen & 21 & & 3 & & 10 & & 2 & & 9 & & 45 \\
\hline
\end{tabular}


Balogh Norbert:

Zár-rés és nazális hangok idötartamának vizsgálata a nápolyi és torinói regionális köznyelvben Argumentum 17 (2021), 83-93

Debreceni Egyetemi Kiadó

DOI: 10.34103/ARGUMENTUM/2021/5

Az összesen 25 [n] nazális mássalhangzó mintavételéből szókezdő ejtésénél hasonló átlagértékeket figyeltem meg: a nápolyi $50 \mathrm{~ms}$ és a torinói $55 \mathrm{~ms}$. A torinói átlagértéket a $40 \mathrm{~ms}$ és 70 ms alkotja. A nagyobb érték majdnem a duplája a kisebb értéknek, tehát megint raddoppiamento sintattico-ról beszélünk a második értéknél, ezt bizonyítja a mássalhangzónyújtás az elemzett hangszövegben.

A zöngés [n] intervokális környezetben a nápolyi köznyelvben 75 ms értékkel bír, míg a torinói $45 \mathrm{~ms}$, amely már önmagában is lényeges mennyiségi eltérést jelez. Ráadásul a nápolyi mintában szereplő 4 hang mért adatai nagyon eltérőek voltak az összes többi hang analitikájával összehasonlítva, ezért az intervokális [n] hangnál szórást is számoltam. A 50 ms-tól 100 ms-ig tartó intervallum szórása $50 \mathrm{~ms}$, míg ugyanez a torinóinál csak $40-50$ ms közötti a mozgástér ezt a 2. ábrán szemléltetem.

A V[n]C környezetet érdemes részletesen megvizsgálni, mert ott a torinói szórás jelentős: 40-100 ms közötti, jóllehet a nápolyi is $60-150 \mathrm{~ms}$, amelyek értékingadozásai rendre $50 \mathrm{~ms}$ átlaggal bírnak és ez mutatkozik az átlagértékükben is: $70 \mathrm{~ms}-100 \mathrm{~ms}$.

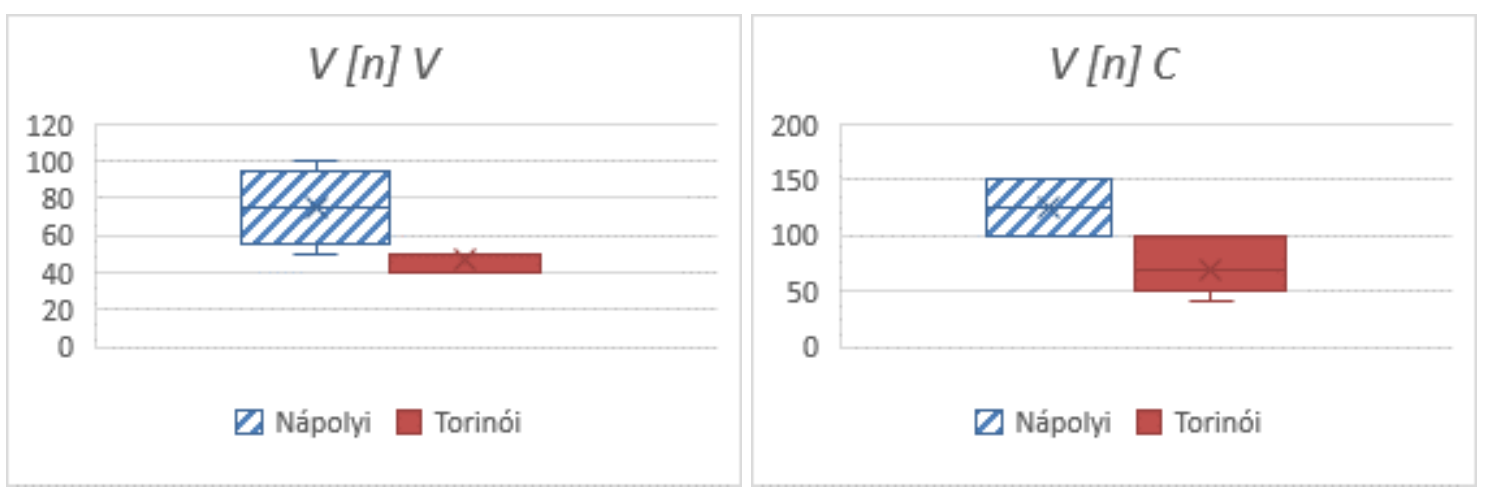

2. ábra. Az intervokális és V_C környezetben előforduló [n] időtartamának szórása

A fenti két ábra mutatja a szóráskülönbségeket, amelyek intervokális [n] esetén a nápolyi köznyelvben mutatnak lényeges eltéréseket, míg a V[n]C környezetben a szórás arányai mindkét nyelvnél nagyok. Ez azt jelenti, hogy az [n] hangot az adott köznyelveken belül is nagyon eltéröen használják.

Az [n:] gemináta szintén csak intervokális helyzetben jöhet létre, a nápolyi értéke 105 ms, amely rendre hozza a 100 ms körüli gemináta értéket.

Végül az utolsó nazális zöngés beszédhang az olaszban az [n], amelyre csak intervokális környezetben találtam példákat: a torinói 1 minta $70 \mathrm{~ms}$ értékkel, és a 3 nápolyi pedig $100 \mathrm{~ms}$ átlagértékkel. Ezek az értékek szintén hozzák rendre a hipotézisben előre jelzett jelenségeket, ahogyan azok a vizsgált köznyelvekre jellemzőek (Canapari 1980: 99).

\section{5 Összefoglalás}

A tanulmány célja az volt, hogy a rámutasson a zár-réshangok és nazális hangok kiejtési különbségeire időtartam szempontjából a nápolyi és torinói köznyelvben vizsgált példákon keresztül. Az alábbi táblázat szemlélteti az affrikátákon és a nazális hangokon mért átlag időtartamot mindkét köznyelvben. 17 hangkörnyezetben tudtam összehasonlító elemzést végezni, 
Balogh Norbert:

Zár-rés és nazális hangok idötartamának vizsgálata a nápolyi és torinói regionális köznyelvben Argumentum 17 (2021), 83-93

Debreceni Egyetemi Kiadó

DOI: 10.34103/ARGUMENTUM/2021/5

mérésekkel alátámasztva, amelyekből 13 esetben a nápolyi köznyelvben nagyobb mérési arányok mutathatók ki, mint a torinói köznyelvben. Tehát a vizsgálat eredménye $76 \%$-ban megerősítette az eredeti feltételezésemet, amely szerint a délolasz köznyelvek vizsgált hangjainak átlagos kiejtési időtartama hosszabb, mint az északolaszoké. A zár-réshangok közül az alveoláris affrikátákra minden helyzetben igaz volt a feltételezésem a nápolyi köznyelvre vonatkozóan, de kevésbé a dentális affrikátákra, ahol a torinói köznyelvben több esetben kaptam nagyobb értéket, mint a nápolyiban. A nazális hangok döntő többsége szintén bizonyította a hipotézist.

\begin{tabular}{|l|r|r|l|}
\hline \multicolumn{1}{|c|}{ Vizsgált hang } & Nápolyi & Torinói & $\begin{array}{c}\text { A nápolyi köznyelv } \\
\text { idötartama nagyobb }\end{array}$ \\
\hline V[t]]V & 38 & 33 & $\checkmark$ \\
[t]]C & 47 & 40 & $\checkmark$ \\
Szókezdő [t]] & 48 & 39 & $\checkmark$ \\
V[t]:]V & 45,5 & 37,5 & $\checkmark$ \\
Szókezdő [dz] & 47,5 & 30 & $\checkmark$ \\
V[dz:]V & 38 & 29 & $\checkmark$ \\
V[dz:]V & 36 & 41 & \\
V[ts]V & 83 & 63 & $\checkmark$ \\
[ts]C & 41 & 65 & \\
V[m]V & 90 & 50 & $\checkmark$ \\
Szókezdő [m] & 25 & 60 & \\
V[m:]V & 140 & 90 & $\checkmark$ \\
V[n]V & 75 & 45 & $\checkmark$ \\
V[n]\# & 60 & 40 & $\checkmark$ \\
V[n]C & 125 & 70 & $\checkmark$ \\
Szókezdő [n] & 50 & 55 & \\
V[n]V & 100 & 70 & $\checkmark$ \\
\hline
\end{tabular}

5. táblázat. Az átlag hangidőtartamok összehasonlitása

Nemcsak a két köznyelv összehasonlításában, hanem mindkét köznyelven belül is számottevően nagy eltérések voltak bizonyos mért adatok között, nevezetesen az intervokális [n] és a $\mathrm{V}[\mathrm{n}] \mathrm{C}$ környezetben, ezért ott az értékek szórását is megmértem, hogy további következtetéseket tudjak levonni. Jóllehet a szórás értékük nagysága megegyezik, viszont azok időintervallumának kezdete és vége eltérő, ami a tényleges kiejtési időtartamok eltérését mutatja.

A négy alany kiejtési időtartamának felmérését egy kis mintán végzett elemzésből tudtam reprezentálni és további általánosításokat levonni az adott köznyelveket illetően. Limitált volt a szókészlet is, hiszen egy felvett interjúból dolgoztam és voltak olyan hangkörnyezetek, amelyek nem jelentek meg mindkét köznyelvben, így nem tudtam azokat érdemben összehasonlítani. Egy szélesebb körü mintavétel és a minden hangkombinációt felölelő szókészlet valószínüleg árnyaltabb képet eredményezne.

Általánosságban elmondható, hogy hasonló jelenség megfigyelését várhatjuk a többi déli és északi kontrasztban is. Az olaszul tanulók és az olasz nyelv iránt érdeklödők ne lepödjenek 
Balogh Norbert:

Zár-rés és nazális hangok idötartamának vizsgálata a nápolyi és torinói regionális köznyelvben Argumentum 17 (2021), 83-93

Debreceni Egyetemi Kiadó

DOI: 10.34103/ARGUMENTUM/2021/5

meg, ha ilyen különbségeket hallanak, mert ez az olasz nyelvhez tartozik, és a regionális köznyelvek sokszínüségükkel tarkítják a mindennapi beszélt nyelvet. További kutatások alapját képezheti más hangcsoportokkal végzett kiejtési időtartam vizsgálat, valamint más regionális köznyelvek összehasonlítása. Érdemes a raddoppiamento sintattico jelenséget is mélyebben megvizsgálni, hogy mely regionális köznyelv használják ki a nyelvnek ezt a fakultatív sajátosságát.

\section{Irodalom}

Absalom, M., Stevenes, M. \& Hajek, J. (2002): A typology of spreading, insertion and delation or what you weren't told about raddoppiamento sintattico in Italian. In: Proceedings of the 2002 Conference of the Australian Linguistic Society.

Boersma, P. \& Weenink, D. (1992): Praat: Doing phonetics by computer (version 6.1.32), http://www.praat.org/ (Letöltés: 2020.12.12.).

Canepari, L. (1980): Italiano standard e pronunce regionali. Padova: Cleup.

Celata, C. \& Calamai S. (2011): Timing in Italian VNC sequences at different speech rates. Firenze: Interspeech.

De Blasi, N. (2014): Geografia e storia dell'italiano regionale. Bologna: il Mulino.

Devoto, G. \& Giacomelli, G. (2002): I dialetti delle regioni d'Italia. Milano: Bompiani.

Grassi, C., Sobrero, A. A. \& Telmon, T. (2004): Fondamenti di dialettologia italiana. RomaBari: Laterza.

Herczeg, Gy. (1992): Olasz leíró nyelvtan. Budapest: Terra.

Kassai, I. (1998): Fonetika. Budapest: Nemzeti Tankönyvkiadó.

Krämer, M. (2009): The Phonology of Italian. Oxford: Oxford University Press.

Laziczius, Gy. (1979): Fonetika. Budapest: Tankönyvkiadó.

Ledgeway, A. \& Maiden, M. (2016): Romance Languages. New York: Oxford University Press. https://doi.org/10.1093/acprof:oso/9780199677108.001.0001

Loporcaro, M. (2009): Profilo linguistico dei dialetti italiani. Bari: Laterza.

Marcato, C. (2002): Dialetto, dialetti e italiano. Bologna: il Mulino.

Nespor, M. \& Bafile, L. (2008): I suoni del linguaggio. Bologna: il Mulino.

Prieto, P., Borràs-Comes, J. \& Roseano, P. (coords.) (2010-2014): Interactive Atlas of Romance Intonation. http://prosodia.upf.edu/iari/index.html (Letöltés: 2020.11.29.)

Stevens, M. (2011): Consonant length in Italian: gemination, degemination and preaspiration. In: Selected Proceedings of the 5th Conference on Laboratory Approaches to Romance Phonology. Ed. Alvord, S. M. Somerville: Cascadilla Proceedings Project, 21-32.

Balogh Norbert

Eötvös Lóránd Tudományegyetem

Nyelvtudományi Doktori Iskola, Romanisztika Doktori Program

H-1088 Budapest,

Múzeum krt. 4/A.

norbi1981@gmail.com 